\title{
A RARE CASE OF INTRAMEDULLARY LIPOMA ASSOCIATED WITH CYST
}

\author{
Asdrubal Falavigna ${ }^{1}$, Ana Claudia Segatto ${ }^{2}$, Karine Salgado $^{3}$
}

\begin{abstract}
Intramedullary lipomas are benign tumours of the spinal cord corresponding to $1 \%$ of all primitive intramedullary tumours. We report a rare case of "true" intramedullary lipoma associated with cyst. The patient underwent subtotal resection and the diagnosis was made by histopathological examination. There was postoperative neurological improvement.
\end{abstract}

KEY WORDS: lipoma, spinal cord, magnetic resonance imaging, dermoid cyst.

Caso raro de lipoma intramedular cístico

RESUMO - Os lipomas intramedulares são tumores benignos da medula espinhal correspondendo a $1 \%$ dos tumores primitivos intramedulares. Relatamos um caso raro de lipoma intramedular "verdadeiro" associado com cisto . O paciente foi submetido a ressecção cirúrgica parcial com melhora neurológica no pós-operatório, sendo o diagnóstico histopatológico de lipoma.

PALAVRAS-CHAVE: lipoma, medula espinhal, ressonância magnética, cisto dermóide.

Lipomas of the spinal cord are uncommon ${ }^{1-4}$. The majority of reports found an incidence of $1 \%$ of all spinal cord tumours ${ }^{5}$. Intramedullary lipomas are even more rare, their incidence being estimated as 0.45 to $0.6 \%$ when they are not associated with spinal cord dysrhaphism ${ }^{6}$. The origin of these lesions is unknown and the clinical presentation may mimic any of a variety of other spinal cord processes ${ }^{7}$.

\section{CASE}

A 48-year-old woman presented with a 10-year history of progressive bladder dysfunction. Five years after the onset of bladder dysfunction, she has developed numbness and a cramp in both lower limbs. At this time, she had a clinical examination and was investigated with electromyography and a lumbar computed tomography (CT) that were normal. There was a gradual worsening of leg numbness with distal anesthesia in the last three months and she was unable to walk unaided in the last month prior to admission. At admission the general physical examination revealed that she was $120 \mathrm{Kg}$ overweight. The cardiovascular and respiratory systems were normal. There were no motor, reflex or sensory changes in the upper extremities. Both lower limbs were spastic with the knee and ankle jerks exaggerated. There were grade IV spastic paraparesis, bilateral. Babinski's sign was positive bilaterally. There was depression of spinothalamic and posterior column sensibility up to the level of D10. Muscle spasms were present in both lower limbs. There were no signs of spinal dysraphism.

Routine blood tests were normal. Urine culture revealed the growth of $E$. coli that was treated with antibiotic therapy. Plain radiographs of the dorsal-lumbar spine were unremarkable. Dorsal MRI (Philips Gyroscan T5-NT) revealed an intradural lesion extending from D11 to D12 displacing the spinal cord anteriorly. The inferior part of the lesion was high-signal intensity on T1-weighted images (TR 450 / TE 15) which was characteristic of a fat component (Fig. 1). At the upper border of the lesion there was a cyst that had the same MRI characteristics as the cerebrospinal fluid on T2-weighted images (TR 3700 / TE 130) with a fat component in the lower portion that appear hyperintense to normal neural parenchyma. There was indefinition of the thoracic spinal cord at the level of the cyst without any gadolinium enhancement (Fig. 2).

Surgery was performed with midline skin incision from spinous process of D10 to L1. There was no evidence of spinal dysraphism after exposure of the laminae. After $X$ ray localization of D10 spinous process, a laminectomy

Disciplina de Neurologia da Faculdade de Medicina da Universidade de Caxias do Sul (UCS): ${ }^{1}$ Professor Assistente da Disciplina de Neurologia da Faculdade de Medicina da Universidade de Caxias do Sul, Mestrando em Neurocirurgia da UNIFESP - Escola Paulista de Medicina de São Paulo; ${ }^{2}$ Médica Residente de Clínica Médica do Hospital Saúde; ${ }^{3}$ Neuropatologista.

Received 3 June 2000, received in final form 4 September 2000. Accepted 11 September 2000. 


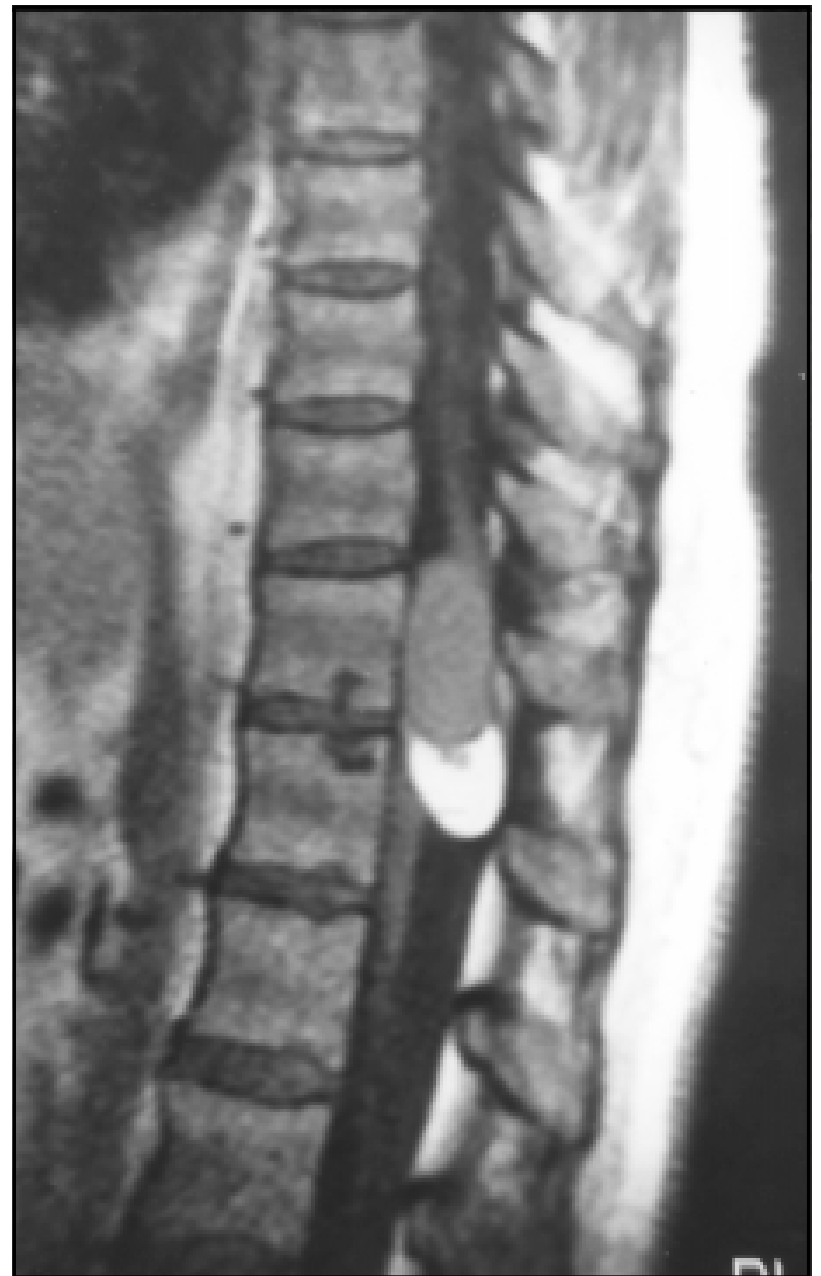

Fig 1. Sagittal section in T1-weighted dorsal resonance images (TR 450 / TE 15) showing the extent of the lesion with an isointensity signal in the upper two-third, corresponding to the cyst, and high-signal intensity of the terminal spinal cord, corresponding to fat. was performed in D11 and D12. It revealed a pale, spindleshaped, non-pulsatile and bulging dural sac. The microscope was introduced into the field. The dura was opened and a yellowish tumor was seen with a cyst on the upper margin. After opening the cyst a plane of cleavage between the tumor and the neural tissue could be defined. In the remaining areas the tumor was continuous to the spinal cord and the nerve roots by a fine, whitish, fibrous capsule. Subtotal removal was, therefore carried out. A watertight dural closure was performed followed by a muscle and skin closure. The pathological examination revealed that the tumor was composed by mature adipocytes with fibrous tissue, smooth tissue, scattered strands of normal nervous tissue and a few vascular channels (Fig 3).

After surgery there was recovery of sensation in the lower limbs and bladder function. Motor power improved allowing her to climb stairs and walk without help. The sensation of cramps disappeared.

\section{DISCUSSION}

Intradural lipomas are often continuous with dorsal subcutaneous fat through dysraphic defects in the posterior neural arch $^{8}$. Spinal lipomas not associated with spinal dysrhaphism in adults are regarded as tumoral and so termed "true" lipomas". Their incidence was estimated to be 0.45 to $0.6 \%$. There is an insignificant sex difference ${ }^{6,9}$. Intramedullary lipomas not associated with spinal dysrhaphism and cutaneous abnormality usually appear neurologically in the third decade ${ }^{10,11}$. They generally have a tendency to extend longitudinally, occupying several segments of the spinal cord ${ }^{12}$. The thoracic area appeares to be most frequently involved ${ }^{1}$.
Fig 2. Axial section in T2-weighted dorsal resonance images (TR 5600 / TE 140) showing the cyst with high-signal intensity occuping the whole spinal canal at D11 level (upper images) and the lipoma expelling the spinal cord in the anterolateral part of the spinal canal at D12 level (lower images).

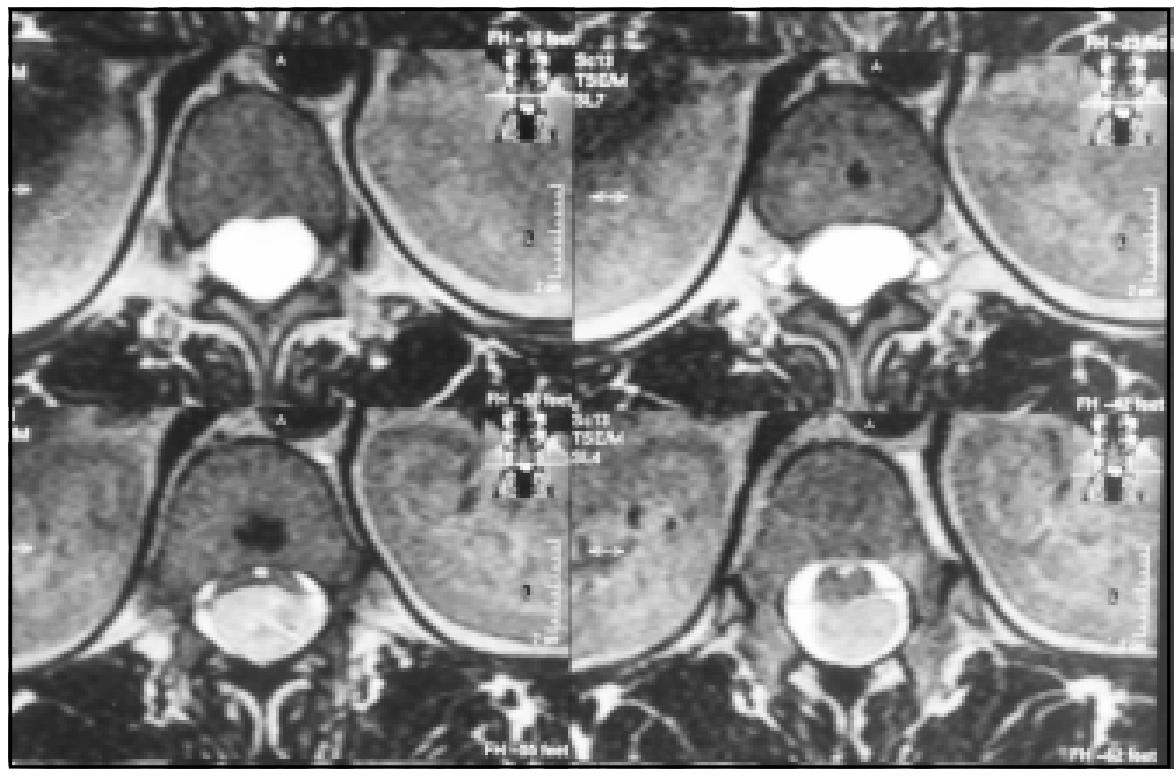




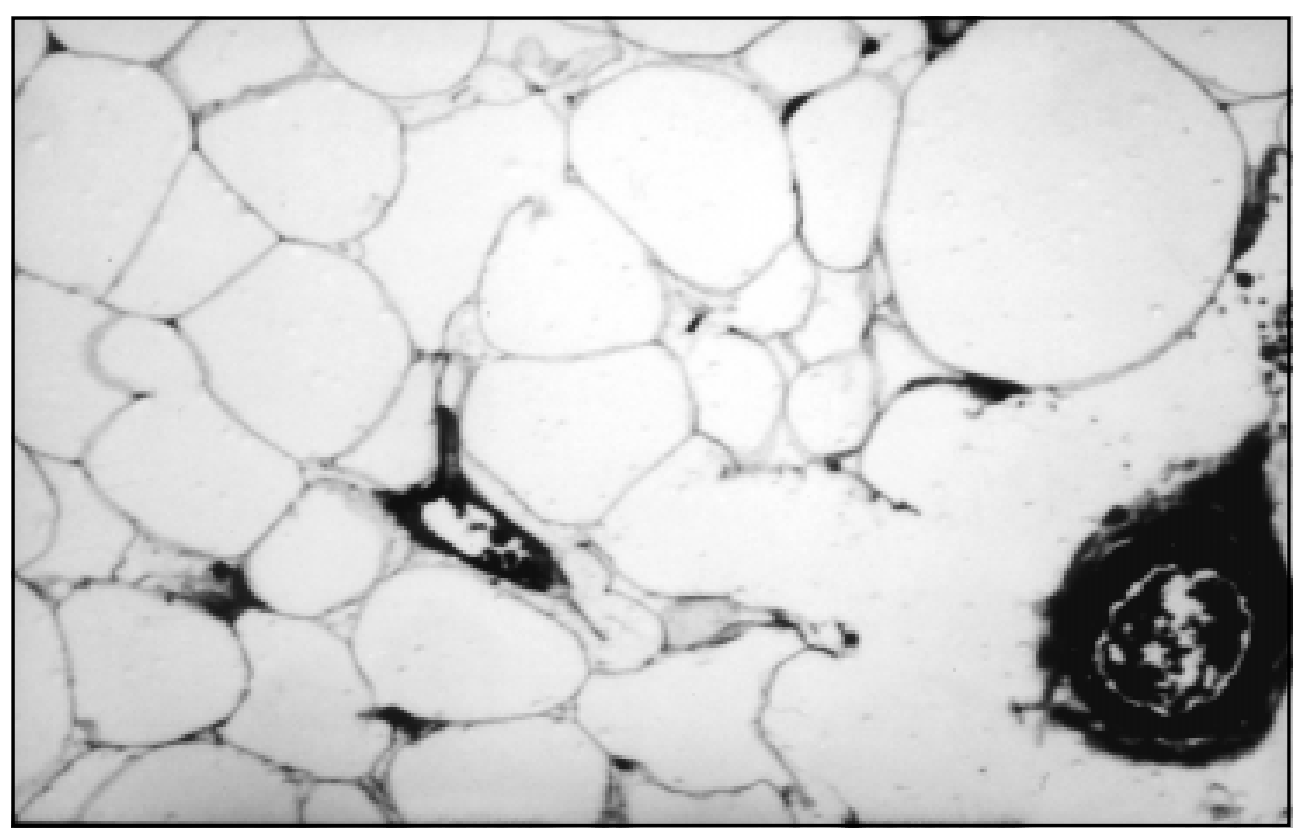

Fig 3. Histologic section of the tumor reveals mature adipocytes with few vascular channels; original magnification x 32 .

The exact pathogenesis of spinal lipoma is still unclear $^{8}$. They are considered embryonic malformations of the neural tube ${ }^{10}$. Bostroem ${ }^{13}$ believed that the lipoma was an inclusion of misplaced primitive cells within the neural tube at the time of its closure. Ehni and Love ${ }^{2}$ postulated the hypothesis that these lipomas are of mesenchymal rather than neural origin and they appear because of local failure control over the formation of fat from the pericapillary mesenchymal cells. As suggested by McClone et al. ${ }^{14}$, spinal cord lipomas are thought to arise from premature disjunction of the cutaneus ectoderm from the forming neural tube.

The neurological abnormalities are variable depending upon the size and location of the lipoma ${ }^{15}$. The clinical course is typically one of slow progression, with occasional remission, which could be related to changes in the systemic metabolism of fat with loss of weight ${ }^{3,5,16}$. Deterioration in the neurological status has been noted during periods of rapid weight gain and in treatment with steroids, which apparently results in the swelling of the lipomatous tissue ${ }^{17}$. Acute spinal cord compression syndromes do not occur, perhaps as a result of the soft texture of the lipoma ${ }^{16}$. Because of the wide variety of clinical manifestations, the differential diagnosis includes both mass lesions and degenerative disorders that may affect the spinal $\operatorname{cord}^{12,18}$. The presence of a subcutaneous lipoma overlying the suspect clinical level in a patient with spinal cord compression, may lead to the clinical diagnosis of an associated intraspinal lipoma in $10 \%$ of cases ${ }^{1}$.
Before the days of CT and MRI, the diagnosis of spinal lipoma could only be suggested by aspecific $\mathrm{X}$-ray features and myelography $1,2,5,8,12,15,17,19$. Worsened clinical signs were observed after lumbar puncture for myelography ${ }^{1,12}$. CT scanning not only readily identifies the fatty nature of the tumour but also defines its extent. MRI visualizes the entire spinal cord and the spinal canal in multiple planes ${ }^{16,17,20}$. In the evaluation of spinal lipomas MRI has proved superior to $\mathrm{CT}$ in the sagittal plane while CT has got the edge over MRI in the axial plane ${ }^{15,20,21}$. In many instances the contrast-enhanced MRI may be the only investigation required prior to surgical intervention ${ }^{11}$. Relaxation times of fat on T2-weighted images are variable and can appear hyperintense, isointense, or hypointense when compared to normal neural parenchyma. However high signal intensity due to the very short relaxation times of fat on T1-weighted images is characteristic of lipomas ${ }^{22}$. There were several reports of intramedullary lipomas associated with syringomyelia and hydromyelia, but its combination with a cyst is rare r $^{1,-5,7,10,15-20,23-26}$.

The main purpose of surgery for lipoma is not total removal but decompression of the adjacent neural structures, since both types, extramedullary and intramedullary lipomas, are closely involved with the surrounding parenchyma and adjacent nerve roots ${ }^{2,3,9,27}$. Subtotal removal carries no higher risk of recurrence than total removal and total removal has resulted in postoperative neurological dysfunction due to disruption of spinal cord ele- 
ments ${ }^{11,17,28}$. The success of surgery depends strictly on the severity of the preoperative neurological deficit and an early intervention is advocated to avoid later irreparable damage. Patients who present with severe neurological involvement are unlikely to improve with surgical resection although pain syndromes have responded well $1,5,17,19$. It should be emphasized that if the spinal cord lipomas are asymptomatic they should be left alone $\mathrm{e}^{4}$. The multiplanar capacity of MRI makes it possible to follow the growth of residual or asymptomatic lipomas.

Histologically, lipomas are an mixture of highly vascularized lobulated fatty tissue separated by delicate connective tissue and interposed in the neural tissue $^{10}$. All intraspinal lipoma cells also have the same metabolic properties as normal adipocytes suggesting that intraspinal lipomas are not lipomatous tumors but hamartomatous lesions, capable of growth and regression and can be influenced by diet and weight gain ${ }^{17,18}$.

In conclusion, pre-operative differentiation between intradural dermoid cyst and lipoma is often unfeasible unless the presence of a dermoid cyst is revealed by the appearance of a characteristic mixedsignal intensity. Particularly in this case, the unusual association with a cyst brings more difficulties to their differential diagnosis.

\section{REFERENCES}

1. Caram PC, Scarcella G, Carton CC. Intradural lipomas of the spinal cord with particular emphasis on the intramedullary lipomas. J Neurosurg 1957;14:28-42.

2. Ehni G, Love JG. Intraspinal lipomas: report of cases, review of literature and clinical and pat hological study. Arch Neurol Psychiatry 1945;53:1-28.

3. Johnson RE, Roberson GH. Subpial lipoma of the spinal cord. Radiology 1974;111:121-125.

4. Razack N, Jimenez OF, Aldana P, Ragheb J. Intramedullary holocord lipoma in an athlete:case rep ort. Neurosurgery 1990;42:394-397.
5. Rogers HM, Long DM, Chou SN, French LA. Lipomas of the spinal cord and cauda equina. J Neurosurg 1987;34:349-354.

6. McCormick PC, Stein BM. Intramedullary tumors in adults. Neurosurg Clin North Am 1990;1:609-630.

7. Dick P. Intramedullary lipoma: diagnosis and treatment. Spine 1992;17:979-981.

8. Love JG, Daly DD, Harris LE. Tight filum terminale: report of condition in three siblings. JAMA 1961;31:176.

9. McLone DG, Naidich TP. Laser resection of fifty spinal lipomas. Neurosurgery 1986;18:611-615.

10. Medjek L, Adjmi M, Hammoum S. Lipomes rachidiens intraduraux: à propos de 2 cas. J Radiol 1992;73:653-656.

11. Fujiwara F, Tamaki N, Nagashima T, Nakamura M. Intradural spinal lipomas not associated with spinal dysraphism: a report of four cases. Neurosurgery 1995;37:1212-1215.

12. Foster JJ. Spinal intradural lipomas. Intern Surg 1966;46:480-486.

13. Bostroem E. Üeber die pialen epidermoid Dermoid und Lipome. Path $1897 ; 8: 1$.

14. McClone DG, Mutluer S, Naidich TP. Lipomeningoceles of the conus medullaris. Concep Pediat Neurosurg 1982;3:170-177.

15. Goyal M, Mishra NK, Gaikwad S, Jayasundar R. Cervical intramedullary lipoma with unusual MRI features: case report. Neuroradiology 1996;38:117-119.

16. Lunardi P, Missori P, Ferrante L, Fortuna A. Long-term results od surgical treatment of spinal lipomas: report of 18 cases. Acta Neurochir 1990;104:64-68.

17. Khamlichi A, Ouahabi A, Amrani F, Agdach R, Bellakhdar F. Lipomes intramédullaires. Neurochirurgie 1989;35:366-370.

18. McGillucuddy GT, Shucart W, Kwan ESK. Intradural spinal lipomas. Neurosurgery 1987;21:343 - 346.

19. Fornari M, Pluchino F, Solero CL, et al. Microsurgical treatment of intramedullary spinal cord tumours. Acta Neurochir 1988;43:(Suppl):3-8.

20. Lantos G, Epstein F, Kay L. Magnetic resonance imaging of intradural spinal lipoma. Neurosurgery 1987;20:469-472.

21. Behari S, Banerji D, Gupta RK, Agarwal P, Chhabra DK. Problems in differentiating intradural lipoma from dermoid on magnetic resonance imaging. Australas Radiol 1997;41:196-198.

22. Wilson JT, Shapiro RH, Wald SL. Multiple intradural spinal lipomata with intracranial extension. Pediatr Neurosurg 1996;24:5-7.

23. Amendola MA, Garfinkle WB, Ostrum BJ, Katz R, Katz RI. Preoperative diagnosis of a rupture intracranial dermoid cyst by computerized tomography. J Neurosurg 1978;48:1035-1037.

24. Stookey B. Intradural spinal lipoma. Arch Neurol Psychiatry 1927;18:16-42.

25. Joubert J, Durrheim DN, Copley IB. Cervical intraspinal lipoma in a pregnant patient. Br J Neurosurg 1993;7:437-441.

26. Swanson HS, Barnett JC. Intradural lipomas in children. Pediatrics 1962;29:911-926.

27. Timmer FA, Van Rooij WJJ, Beute GN, Teepen JLJM. Intramedullary lipoma. Neuroradiology 1996;38:159-160.

28. Cooper PR, Epstein F. Radical resection of intramedullary spinal cord tumors in adults recent experience in 29 patients. J Neurosurg 1985;63:492-499. 